\title{
Molecular Characterization of Hepatitis B Virus Strains Isolated from Chronic Hepatitis B Patients in Southeastern Region of Turkey
}

\author{
Türkiye'nin Güneydoğu Bölgesi'ndeki Kronik Hepatit B Hastalarından Izole Edilen \\ Hepatit B Virüsü Sușlarının Moleküler Karakterizasyonu
}

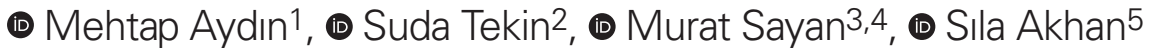 \\ 1/stanbul Sultan Abdülhamid Han Training and Research Hospital, Clinic of Clinical Microbiology and Infectious Disease, Istanbul, Turkey \\ ${ }^{2}$ Koç University Faculty of Medicine, Department of Clinical Microbiology and Infectious Disease, Istanbul, Turkey \\ ${ }^{3}$ Kocaeli University Faculty of Medicine, Department of Clinical Laboratory, Division of PCR Unit, Kocaeli, Turkey \\ ${ }^{4}$ Near East University Research Center of Experimental Health Sciences, Nicosia, Turkish Republic of Northern Cyprus \\ 5 Kocaeli University Faculty of Medicine, Department of Clinical Microbiology and Infectious Disease, Kocaeli, Turkey
}

\begin{abstract}
Objectives: The aim of the present study was to assess the molecular aspects of HBV strains isolated from chronic hepatitis B (CHB) patients, in the Southeastern region of Turkey.

Materials and Methods: The study involved a total of 110 patients, 57 of them were treatment naive. 53 were undergoing nucleos $(t) i d e$ analogue (NUC) therapy, whom were diagnosed with $\mathrm{CHB}$ between July 2010 and April 2011 in the Southeastern region of Turkey. We analysed the HBV pol gene by amplification and direct sequencing with using polymerase chain reaction.

Results: The phylogenetic and genotype analysis showed that all $(100 \%)$ of the patients were infected with HBV genotype D. The prevalence of antiviral drug-associated potential vaccine-escape mutant was $10.5 \%$ among treatment naive and $15 \%$ NUC therapy group. S gene mutation among treatment naive group and NUC therapy group were $19 \%$ and $26.4 \%$.

Conclusion: Determination of genotypes/subgenotypes of HBV may provide robust epidemiological data related to their circulation as well as their transmissibility. However, the findings of $\mathrm{HBV}$ pol gene mutations may be helpful in the management of rescue strategies in NUCs resistant patients in Southeastern region of Turkey.

Keywords: Hepatitis B virus, HBV polymerase gene mutation, Nucleos(t)ide analogue
\end{abstract}

ÖZ

Amaç: Türkiye'deki hepatit B enfeksiyonunun prevalansı Güneydoğu Bölgesi'nde diğer bölgelere göre daha yüksektir. Hepatit B genomundaki mutasyonlar kronik hepatit B hastalarının tanı ve tedavisinde güçlüklere sebep olmaktadır. Bu çalışmanın amacı, yüksek endemisiteye neden olan sebeplerinin ve belirli bir suşun bölgede yaygın olup olmadığının değerlendirilmesidir

Gereç ve Yöntemler: Haziran 2010 ve Nisan 2011 tarihleri arasında Türkiye'nin Güneydoğu Bölgesi'nde kronik hepatit B tanısı alan toplam 110 hasta çalışmaya katıldı. Hastaların 57'si tedavi deneyimsiz iken 53'ü nükleosid analog (NUC) tedavisi almaktaydı.

HBV pol geni amplifikasyon ve direct sekanslama polimeraz zincir reaksiyonu ile analiz edildi.

Bulgular: HBV virusunun filogenetik ve genotip analizi sonucunda hastaların hepsinin (\%100) HBV genotip D ile enfekte olduğu görüldü. Antiviral ilaç ilişkili potansiyel aşı kaçak mutantlarının prevalansının tedavi deneyimsiz grupta \% 10,5 NUC tedavisi alan grupta \% 15 olduğu bulundu. S gen mutasyonu tedavi deneyimsiz grupta ve NUC tedavisi alan grupta sırasıyla \%19 ve \%26,4 olarak saptandı.

Sonuç: HBV'nin genotip/subgenotip tayini, virusun yaygınlığı ve bulaşıclığı hakkında gücçlü epidemiyolojik veriler sağlayabilir. Bununla birlikte HBV pol gen mutasyonları ile ilgili bu bulgular, Türkiye'nin Güneydoğu bölgesindeki NUC dirençli hepatit B hastalarında tedavi stratejilerinin yönetiminde yararlı olabilir.

Anahtar Kelimeler: Hepatit B virüsü, HBV polimeraz gen mutasyonu, Nucleos(t)ide analoğu

Aydın M, Tekin S, Sayan M, Akhan S. Molecular Characterization of Hepatitis B Virus Strains Isolated from Chronic Hepatitis B Patients in Southeastern Region of Turkey. Viral Hepat J. 2019;25:40-44. 


\section{Introduction}

Hepatitis B virus (HBV) infection is endemic at an intermediate to high range within Turkey. The regional hepatitis $B$ surface antigen (HBsAg) prevalence is ranging from $2.5 \%$ to $9.1 \%$ with the higher values concentrated in the Southeastern part of Turkey (1).

The HBV polymerase (pol) gene completely overlaps the envelope gene (2). Mutations in and around the major neutralization domain of HBV known as the "a" determinant, may cause HBV reactivation, diagnostic problems, failure in prophylaxis through vaccination or failure in prophylaxis by administering hepatitis $B$ immunoglobulin (3).

The usage of low genetic barrier/potency drugs such as lamivudine (LAM) in medium-to-high HBV prevalence countries, antiviral drug-associated potential vaccine-escape mutant (ADAPVEM), is becoming a growing health concern (4). The public health significance of such mutant pol-envelop overlaps, were recently highlighted when the up to then, theoretical concerns about NUC-resistant HBV, potentiating behaviour as a vaccine escape virus was actually observed in chimpanzees. This drug resistant virus strain was genetically fit and stable, however its' altered envelope escapes the anti-HBs neutralization (5). Transmissions of ADAPVEMs are of critical concern in the control of HBV infections. The generally accepted method for the control of the latter is prevention through vaccination. A secondary approach is the prevention of clinical complications of chronic HBV infections through specific and effective oral antiviral treatments. These being significantly more potent, with higher genetic barriers to resistance, compared to LAM, telbivudine or adefovir (ADV) $(5,6)$.

In this study our aim was to identify the molecular aspects of HBV strains isolated from CHB patients in the Southeastern Region of Turkey where the endemicity is particularly high. We have focused our attention to identify some of the reasons for this high endemicity and whether it is due to a particular strain being prevalent in the region.

\section{Materials and Methods}

The informed consents (in Turkish) were obtained from all participants before blood sampling. This study was approved by the Ethical Committee Harran University Faculty of Medicine (approval number: 06/10, date: 02.12.2010).

\section{Patients}

Between the dates of July 2010 and April 2011, a total of $110 \mathrm{CHB}$ patients, ages between from 5 to 70 years, with a mean age of 32 years and having a $26 \%$ male and $74 \%$ female ratio, were enrolled to this retrospective study. $\mathrm{CHB}$ infection is defined as the persistence of HBsAg ongoing for 6 months from the date of its first detection. In the beginning of the study 53 patients were already undergoing nucleos(t)ide analogue (NUC) therapy and 57 of the patients were treatment naive.

The patient group undergoing NUC-therapy were receiving LAM (18/53), ADV (1/53), entecavir (ETV) (18/53) and tenofovir (TDV) respectively (16/53).

Inclusion criteria:

- CHB infection with hepatitis B e antigen (HBeAg)-positive or negative
- Treatment naive CHB patients: No previous treatment with Interferon-alpha or NUC,

- CHB Patients already on NUC treatment,

- CHB Patients with compensated liver functions.

Exclusion criteria:

- Co-infection with hepatitis C, hepatitis D, or the human immunodeficiency virus;

- The presence of other forms of liver disease.

Procedures;

The liver damage was classified with Knodell et al. (7) and scaled from 0 to 18 by the histology activity index. Blood samples were separated by centrifugation and the serum was stored at $-20{ }^{\circ} \mathrm{C}$ until testing. The respective aspartate aminotransferase and alanine aminotransferase levels were measured in the serum by spectrophotometric analysis using standard diagnostic kits (Roche Diagnostics, Mannheim, Germany).

Serological markers of HBV (HBsAg), HBeAg, and antibodies to $\mathrm{HBeAg}$ were tested using commercially available micro particle enzyme immunoassay kits, (Axsym, Abbott Laboratories, IL, USA and Elecsys, Roche Diagnostics, Mannheim, Germany).

\section{HBV-DNA Detection}

The HBV-DNA was isolated from the serum sample using the bio-robot workstation, with magnetic-particle technology (QIA symphony SP, Qiagen GmbH, Hilden, Germany). HBV-DNA was detected and quantified by polymerase chain reaction (PCR) assay (artus HBV QS-RGQ test, Qiagen GmbH, Hilden, Germany) on the real-time platform (Rotor-gene Q, Qiagen $\mathrm{GmbH}$, Hilden, Germany).

\section{HBV Sequencing}

A pair of primers (forward: 5'-TCGTG GTGGACTTCTCTCAATT-3' and reverse: 5'-CGTTGACAGACTTTCCAATCAAT-3') were used for the amplification of the HBV pol gene region. The up mentioned pol gene sequence was already being utilized in our laboratory, for routine HBV genotyping and genotypic resistance analysis). The PCR conditions were determined as in preceeding study (8).

\section{The Determination of HBV Genotypes and Pol/Surface Gene Mutations}

We used a phylogenetic analysis and genotyping tool (Gheno2pheno) which accepts nucleic acid sequences for the determination of the HBV genotypes as input. The Geno2pheno has a database that is specifically designed for rapid computerassisted virtual phenotyping of HBV, (Centre of Advanced European Studies and Research, Bonn, Germany, http://coreceptor.bioinf.mpiinf.mpg.de/).

The Geno2pheno searches for homology between the input sequences and others already stored in its database. Additionally stores relevant clinical data for HBV genotypes, drug resistance and S-gene mutations. The tool also searches for HBV drug resistance mutations in the rt domain of the pol gene (9).

The genotypic resistance mutations to the NUCs have been categorized as primary or compensatory (3). In our study the overlapping S-gene segment of HBV strain was searched by Geno2pheno and in parallel was checked against previously recorded ADAPVEM HBsAg amino acid substitutions 
within its database (10). Some mutations especially ADAPVEMs which were not located in the "a" determinant of the HBsAg protein were observed. The other major neutralising domains of the HBsAg proteins were analysed.

\section{Statistical Analysis}

Data entries, determining the mean and the median of different parameters and other preliminary calculations were done on Microsoft Excel. There is no comparison since the prevalence and frequency of the data were given in our study. Genomic values based on bioinformatics were evaluated using bioinformatics-based genotypic rules Geno2Pheno (SVMs) (Centre of Advanced European Studies and Research, Bonn, Germany). Our study does not include statistical significance.

\section{Results}

The Gheno2pheno identified that all (100\%) of the patients were infected with the HBV genotype D. Among these, the $96.4 \%$ of the patients were infected with the sub genotype D1 in the phylogenetic tree. The remaining, $2.7 \%$ and $0.9 \%$ of the strains were identified as the sub genotypes D2 and D3 respectively (Table 1).

Compensatory (23\%) and primary drug-resistance mutations (7\%), ADAPVEM (10.5\%) and S-gene mutations (11\%) were detected in 34/57 (60\%) among treatment naive group (Table 2). The ratio of these mutations among patients with viral breakthrough under NUC therapy were $28 \%, 16.6 \%, 16.6 \%$ and $0 \%$ in 18 LAM group, 5.5\%, 5.5\%, 11\%, 22\% in 18 ETV group, 0\%, 0\%, 0\% and $100 \%$ in ADV group and $0 \%, 12.5 \%, 18.7 \%, 43.7 \%$ in TDV group, respectively (Table 3 ). Six different motifs of ADAPVEM were detected among the CHB patients: rtM250R/sW172L, rtT184G/sL176V, rtM204I/sW196L, rtM204I/sW196S, rtM204V/ sl195M, and rtA181V/sL173F. The frequency of ADAPVEM was $12.7 \%(14 / 110)$ in the total CHB patients. The prevalence of S-gene mutation among treatment naive group and NUC therapy group were $19 \%(11 / 57)$ and $26.4 \%(14 / 53)$ respectively (Table 2,3).

\section{Discussion}

Eight different genotypes ( $\mathrm{A}-\mathrm{H}$ ) of the HBV genome are endemic in different regions of the world (11). The genotype $D$ is prevalent around the Mediterranean Region, the Middle East, and India (12). Sheldon and Co showed that, the mutations in the HBsAg

\begin{tabular}{|l|l|}
\hline \multicolumn{2}{|l|}{ Table 1. Clinical and laboratory characteristics of the study population } \\
\hline Male \%, Female \% & $26 \%, 74 \%$ \\
\hline Mean age, (range) & $32(5-70)$ \\
\hline ALT, median IU/L (range) & $81(23-367)$ \\
\hline AST, median IU/L (range) & $55(16-298)$ \\
\hline HBV-DNA, median copies/mL (range) & $1.2+E 9(2+E 4-3.2+E 10)$ \\
\hline HBV genotype (\%) & D (100) \\
\hline - Sub genotype (\%) & - D1 (96.4) \\
\cline { 2 - 2 } & - D2 (2.7) \\
\cline { 2 - 2 } & - D3 (0.9) \\
\hline $\begin{array}{l}\text { ALT: Alanine aminotransferase, AST: Aspartate aminotransferase, HBV: } \\
\text { Hepatitis B virus }\end{array}$
\end{tabular}

among LAM treated patients, were higher in the HBV genotype A compared to the HBV genotype D (3). Previous studies have identified the genotype $D$ as being the dominant genotype among CHB patients in Turkey (13). We have similarly observed that all $(100 \%)$ of our patients were infected with the HBV genotype D.

Replication defects in HBV caused by mutations under the NUC therapy, can be partially repaired by compensatory mutations (3). In our study the prevalence of compensatory mutations among untreated patients were 23\%. The mutation patterns are listed as L91I, Q149K, I169V/X, V191F, and Q215H/P/S. The prevalence of compensatory mutations among NUC treated patients were $28 \%$ in the LAM treated group. The mutation patterns were L91I or N139K or Q215P or N238T. A sole mutation pattern (A194X) was observed in ETV treated patients and the prevalence was measured as 5.5\%. The $\mathrm{rtQ} 215 \mathrm{H} / \mathrm{Q} / \mathrm{P} / \mathrm{S}$ compensatory mutations are frequently detected both in treatment naive and NUC treated patients $(8,13)$. We, as well, have detected the $\mathrm{rtQ} 215 \mathrm{H} / \mathrm{Q} / \mathrm{P} / \mathrm{S}$ mutations both in treatment naive and LAM treated groups. In a previous paper, the rtL180M mutation was found to be the most common compensatory mutation in a general study among Turkish patients (14). Interestingly, in our study we weren't able to detect any rtL180M mutation.

In our study the prevalence of rt gene mutations among untreated patients was observed as $7 \%$. The mutation patterns were $\mathrm{V} 173 \mathrm{M}$ or A181P or I233V or M250R. The same mutation patterns were observed both in the LAM (L80I + rtL180M + rtM204I, T184E/G, M204I) and the ETV (L180M + T184V + M204V) treated patients. However the frequency was higher in the LAM (16.6\%) treated patients compared to ETV (5.5\%) treated patients. RtL180M + rtM204l, mutations were found among LAM treated patients in a previous study as well. Differing from our results, in this same previous study rt A181V and rt Q215S had also been observed (15).

Some of the mutations in the polymerase gene of HBV are associated with alterations in the "a" determinant of the HBsAg protein. These mutations change the antigenicity of the HBsAg. Such changes may reduce the efficiency of the antibodies induced by the recombinant vaccine (16). In our study we have identified that the vaccine escape HBsAg mutations consist of F161L/H, S193L, M250R/N172, T184G/L176V, M204I/ W196L, M204IM196S, M204V/I95M, M204V/I195M, A181V/ L173F or W172L. The prevalence of ADAPVEM was observed to be $10.5 \%$ among untreated patients while it was $16.6 \%$ with LAM, 11\% with ETV, and 18.7\% with TDF treatment. Compared to those found in another study held in the northwest region of Turkey, the frequencies of ADAPVEM among untreated and treated patients were found to be higher in our study (15). Additionally, the mutation patterns of the ETV treated patients in our study were different from another previous study. The latter study identified rt I169T, rtT184C, rtT184L/S, rtT184G/M, rtS202C/G and rt S202I mutations. Interestingly, our study identified completely different M204V/I195M, S193L mutation patterns (17). The TDF treated ADAPVEMs were M204V/I195M, A181V/L173F, W172L in our patients. Both studies had only one matching mutation, which was identified as rtA181V (17). 


\begin{tabular}{|c|c|c|c|c|}
\hline $\begin{array}{l}\text { Treatment naive group } \\
(\mathrm{n}=57)\end{array}$ & Compensatory mutation & Primary drug resistance mutation & ADAPVEM & S-gene mutation \\
\hline & $\begin{array}{l}\text { L91I } \\
\text { Q149K } \\
\text { I169V/X V191F } \\
\text { O215H/P/S } \\
13(23 \%)\end{array}$ & $\begin{array}{l}\text { V173M } \\
\text { A181P } \\
\text { I233V M250R } \\
4(7 \%)\end{array}$ & $\begin{array}{l}\mathrm{F} 161 \mathrm{~L} / \mathrm{H}^{*} \mathrm{~S} 193 \mathrm{~L} * \\
\mathrm{M} 250 \mathrm{R} / \mathrm{W} 172 \mathrm{~L} \\
6(10.5 \%)\end{array}$ & $\begin{array}{l}\text { Q101R } \\
\text { I110L } \\
\text { T118A } \\
\text { G119I } \\
\text { P120S } \\
\text { P127T } \\
\text { G130R } \\
\text { S132S/Y } \\
\text { T140I } \\
\text { S143L } \\
\text { D144E } \\
11(19 \%)\end{array}$ \\
\hline
\end{tabular}

\begin{tabular}{|c|c|c|c|c|}
\hline NUC treated $(n=53)$ & Compensatory mutation & Primary drug resistance mutation & ADAPVEM & S-gene mutation \\
\hline $\begin{array}{l}\text { Lamivudine } \\
(\mathrm{n}=18)\end{array}$ & $\begin{array}{l}\text { L91I } \\
\text { N139K } \\
\text { Q215P } \\
\text { N238T } \\
5(28 \%)\end{array}$ & $\begin{array}{l}\text { L80I + L180M + M204I } \\
\text { T184E/G } \\
\text { M204I } \\
3(16.6 \%)\end{array}$ & $\begin{array}{l}\text { T184G/L176V } \\
\text { M204I/W196L } \\
\text { M204I/W196S } \\
3(16.6 \%)\end{array}$ & $\begin{array}{l}\text { Q101R } \\
\text { Y134F } \\
2(11 \%)\end{array}$ \\
\hline $\begin{array}{l}\text { Adefovir } \\
(n=1)\end{array}$ & - & - & - & $\begin{array}{l}\text { S132F } \\
1(100 \%)\end{array}$ \\
\hline
\end{tabular}

\section{Study Limitations}

The number of the subjects could have been increased.

\section{Conclusion}

In this study we evaluated the mutations involving the polymerase/surface gene sequence changes in HBV patients with pre-existing, naturally occurring or with undergoing NUC treatments.

These findings are important to determine the prevalence and type of developing variants to NUCs. Further studies are needed to understand the clinical significance of these polymerase/surface gene sequence changes. We strongly suggest that, every patient who has been diagnosed with $\mathrm{CHB}$, should be checked for the baseline polymerase/ surface gene sequence changes, before initiating treatment. This report on the molecular characterization of HBV is the first of its kind within the Southeastern Region of Turkey. We wish that the results of our study will contribute to the decision-making processes and the choise of the treatment in the future.

\section{Ethics}

Ethics Committee Approval: This study was approved by the Ethical Committee Harran University Faculty of Medicine (approval number: 06/10, date: 02.12.2010).

Informed Consent: The informed consents (in Turkish) were obtained from all participants before blood sampling.

Peer-review: Externally peer-reviewed.

\section{Authorship Contributions}

Surgical and Medical Practices: S.T., M.S., Concept: S.A., S.T., Design: M.A., S.A., Data Collection or Processing: S.T., M.S., Analysis or Interpretation: M.S., M.A., Literature Search: M.A., Writing: M.A. 
Conflict of Interest: No conflict of interest was declared by the author

Financial Disclosure: The authors declared that this study received no financial support.

\section{References}

1. Tozun N, Ozdogan O, Cakaloglu Y, Idilman R, Karasu Z, Akarca U, Kaymakoglu S, Ergonul O. Seroprevalence of hepatitis B and C virus infections and risk factors in Turkey: a fieldwork TURHEP study. Clin Microbiol Infect. 2015;21:1020-1026.

2. Torresi J. The virological and clinical significance of mutations in the overlapping envelope and polymerase genes of hepatitis B virus. J Clin Virol. 2002;25:97-106.

3. Sheldon J. Soriano V. Hepatitis B virus escape mutants induced by antiviral therapy. J. Antimicrob Chemother. 2008;61:766-768.

4. Clements CJ, Coghlan B, Creati M, Locarnini S, Tedder RS, Torresi J. Global control of hepatitis B virus: does treatment-induced antigenic change affect immunization? Bull World Health Organ. 2010;88:66-73.

5. Locarnini S. Transmission of antiviral drug resistant hepatitis B virus: implications for public health and patient management. $J$ Gastroenterol Hepatol. 2010;25:649-651.

6. Zanetti AR, Van Damme P, Shouval D. The global impact of vaccination against hepatitis $\mathrm{B}$ : a historical overview. Vaccine. 2008;26:6266-6273

7. Knodell RG, Ishak KG, Black WC, Chen TS, Craig R, Kaplowitz N, Kiernan TW, Wollman J. Formulation and application of a numerical scoring system for assessing histological activity in asymptomatic chronic active hepatitis. Hepatology. 1981;1:431-435.

8. Sayan $M$, Sentürk $O$, Akhan SÇ, Hülagü $S$, Cekmen MB Monitoring of hepatitis $B$ virus surface antigen escape mutations and concomitantly nucleos(t)ide analog resistance mutations in Turkish patients with chronic hepatitis B. Int J Infect Dis. 2010;14:136-141.
9. Shaw T, Bartholomeusz A, Locarnini S. HBV drug resistance: mechanisms, detection and interpretation. J Hepatol. 2006;44:593606.

10. Sayan M, Cavdar C, Dogan C. Naturally occurring polymerase and surface gene variants of hepatitis B virus in Turkish hemodialysis patients with chronic hepatitis B. Jpn J Infect Dis. 2012;65:495501.

11. Enomoto M, Tamori A, Nishiguchi S. Hepatitis B virus genotypes and response to antiviral therapy. Clin Lab. 2006;52:43-7.

12. Zehender G, Ebranati E, Gabanelli E, Shkjezi R, Lai A, Sorrentino C, Lo Presti A, Basho M, Bruno R, Tanzi E, Bino S, Ciccozzi M, Galli M. Spatial and temporal dynamics of hepatitis B virus D genotype in Europe and the Mediterranean Basin. PLoS One. 2012;7:e37198.

13. Akhan S, Aynıŏlu A, Cağatay A, Gönen I, Günal Ö, Kaynar T, Kuruüzüm Z, Sayan $M$, Tunca $B$, Tülek N, Üçkardeş $H$, Yavuz A, Yıldız O, Yılmaz N, Yüksel E. Kronik Hepatit B Virusu Infeksiyonunun Yönetimi: Türk Klinik Mikrobiyoloji ve Infeksiyon Hastalıkları Derneği Viral Hepatit Calıșma Grubu Uzlașı Raporu. Klimik Dergisi 2014;27:2-18.

14. Sayan M. New approach to managing occult hepatitis B infection. Hepat Mon. 2011;11:299-300.

15. Sayan M, Sentürk O, Akhan SÇ, Hülagü $S$, Cekmen MB. Monitoring of hepatitis $B$ virus surface antigen escape mutations and concomitantly nucleos(t)ide analog resistance mutations in Turkish patients with chronic hepatitis B. Int J Infect Dis. 2010;14:136-141

16. Coppola N, Onorato L, Minichini C, Di Caprio G, Starace M, Sagnelli C, Sagnelli E. Clinical significance of hepatitis B surface antigen mutants. World J Hepatol. 2015;7:2729-2739.

17. Sayan M, Akhan SC. Antiviral drug-associated potential vaccineescape hepatitis B virüs mutants in Turkish patients with chronic hepatitis B. Int J Infect Dis. 2011;15:722-726. 